\title{
Effect of wind on performance of double slope solar desalination still for fresh water production.
}

\section{Efecto del viento sobre el rendimiento del destilador solar de desalación de doble pendiente para la producción de agua dulce. \\ Sivakumar C K, Y Robinson}

Department of Mechanical Engineering, RVS Technical Campus- Coimbatore, Coimbatore, Tamil Nadu, India, 641402. Corresponding Author Mail ID: kumarabc464@gmail.com

\section{ABSTRACT}

This study aimed at investigating the effect of wind for double slope solar desalination still. Two double slope solar stills were designed, constructed and experimentally tested their performance depending up on the wind. One experiment carried out with a wind speed of $4 \mathrm{~m} / \mathrm{s}$ and other $3 \mathrm{~m} / \mathrm{s}$. The results show that the variation in wind affects the fresh water production. Double slope solar desalination still with wind speed $4 \mathrm{~m} / \mathrm{s}$ gives $17.8 \%$ higher productivity compare to $3 \mathrm{~m} / \mathrm{s}$.

Keywords: wind, freshwater production, desalination.

\section{RESUMEN}

Este estudio tuvo como objetivo investigar el efecto del viento para la desalación solar de doble pendiente. Se diseñaron, construyeron y probaron experimentalmente dos alambiques solares de doble pendiente en función del viento. Un experimento realizado con una velocidad del viento de $4 \mathrm{~m} /$ sy otro de $3 \mathrm{~m} / \mathrm{s}$. Los resultados muestran que la variación del viento afecta la producción de agua dulce. La desalinización solar de doble pendiente con una velocidad del viento de $4 \mathrm{~m}$ / s proporciona un 17,8\% más de productividad en comparación con $3 \mathrm{~m} / \mathrm{s}$. Palabras clave: viento, producción de agua dulce, desalación.

\section{INTRODUCTION}

Solar desalination is a process to convert saline water to portable water by using solar energy, to improve the productivity of solar stills are coupled with pre heaters such as solar concentrators and solar flat plate collectors. other parameters are also influenced for fresh water production. The structure of the still and tilt angle of the glass cover is one of the major parameter ,less glass cover thickness gives more output .and the depth of the water inside the still also kept minimum for maximum fresh water 
Sustainability, Agri, Food and Environmental Research, (ISSN: 0719-3726), 10(X), 2022:

http://dx.doi.org/

production .the wind also a major part of the solar desalination system.

This study deals with two double slope inward solar desalination still are constructed, and tested at same date and time one is experiment with a wind speed limit of $3 \mathrm{~m} / \mathrm{s}$ and other is $4 \mathrm{~m} / \mathrm{s}$ and data's are collected and plotted graphs.

\section{MATERIALS AND METHODS}

Two double slope inward solar stills having base area $1 \mathrm{~m}^{2}$ and two fans are used to wind supply the inlet of the double slope desalination still connects to saline water tank the experiment conducted from 8 am to $8 \mathrm{pm} .4 \mathrm{~mm}$ glass cover is used and water depth keep $5 \mathrm{~mm}$ constantly j-type thermocouples are used to measure the temperature at inlet and outlet of the still and wind velocity measure by using anemometer.

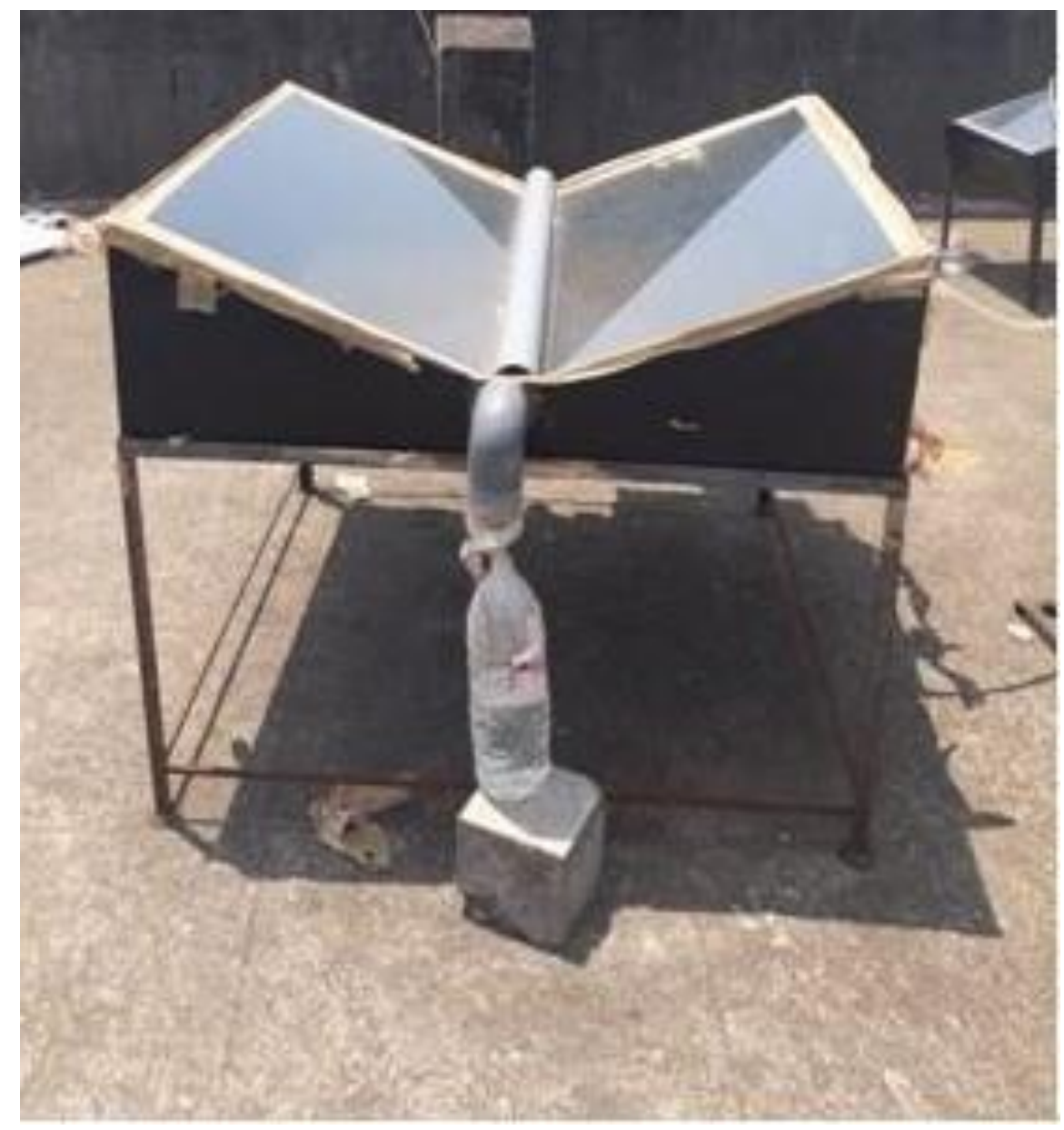

Figure 1.Double slope desalination still 
Sustainability, Agri, Food and Environmental Research, (ISSN: 0719-3726), 10(X), 2022:

http://dx.doi.org/

Table 1: Features of thermocouple

\begin{tabular}{ccc}
\hline Sr. No. & Item & Specification \\
\hline 1 & Type of thermo-couple & J - Type Iron constantan thermocouple \\
2 & Alloy of positive wire & Iron $(100 \% \mathrm{Fe})$ \\
3 & Alloy of negative wire & Constantan $(55 \% \mathrm{Cu}-45 \% \mathrm{Ni})$ \\
\hline 4 & Temperature range & $0-7500 \mathrm{C}$ \\
\hline
\end{tabular}

Table 2: Features of anemometer

\begin{tabular}{|c|c|c|c|c|}
\hline SI. No. & Item & Specification & & \\
\hline 1 & Type of anemometer & Vane type digital anemometer & & \\
\hline 2 & Operating temperature & 0 to $50^{\circ} \mathrm{C}$ & & \\
\hline 3 & Operating humidity & Less than $80 \% \mathrm{RH}$ & & \\
\hline \multirow[t]{2}{*}{4} & Measurement in $\mathrm{m} / \mathrm{s}$ & Range & Resolution & Accuracy \\
\hline & $0.4-30 \mathrm{~m} / \mathrm{s}$ & $0.1 \mathrm{~m} / \mathrm{s}$ & $\pm 2 \%+0.2 \mathrm{~m} / \mathrm{s}$ & $0.4-30 \mathrm{~m} / \mathrm{s}$ \\
\hline
\end{tabular}

\section{RESULTS AND DISCUSSION}

Figure 1 shows the graph of cumulative fresh water collected with respected to solar radiation $\left(\mathrm{w} / \mathrm{m}^{2}\right)$ with respected to time the readings are taken between morning 8 am to evening $8 \mathrm{pm}$.the cumulative fresh water collected with wind speed of 3m/s was $2045 \mathrm{ml}$. where series 1 represented solari meter reading and series 2 represented cumulative water collected

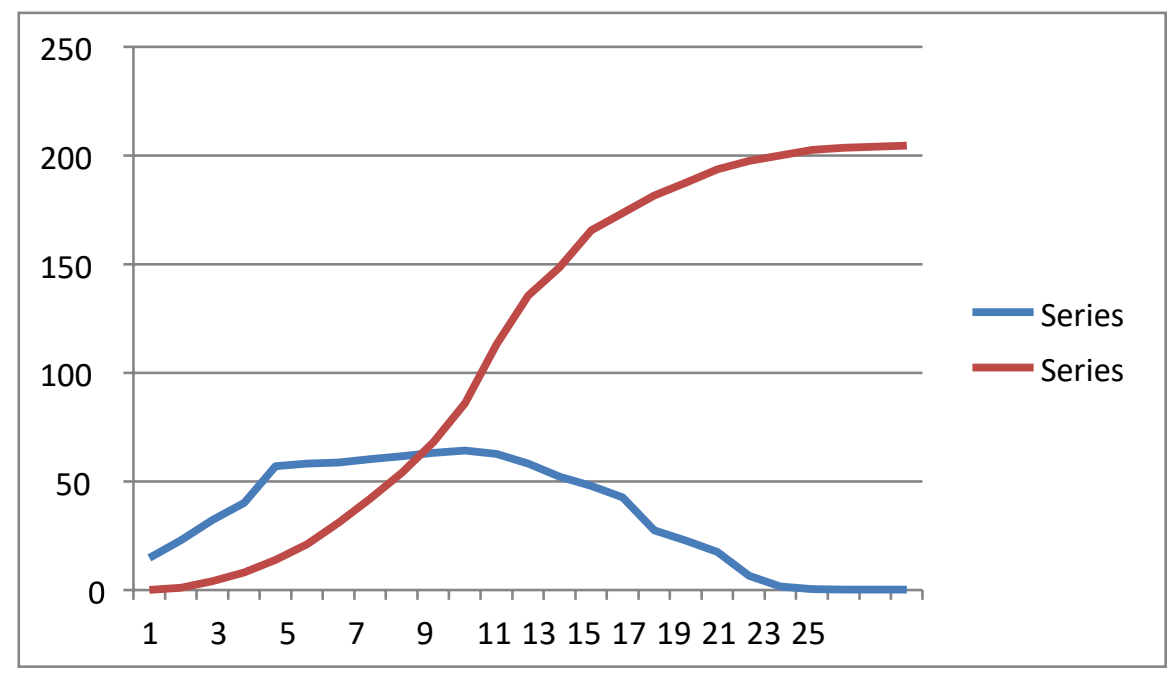

Fig 1: solari meter reading Vs cumulative water collected 
Sustainability, Agri, Food and Environmental Research, (ISSN: 0719-3726), 10(X), 2022: http://dx.doi.org/

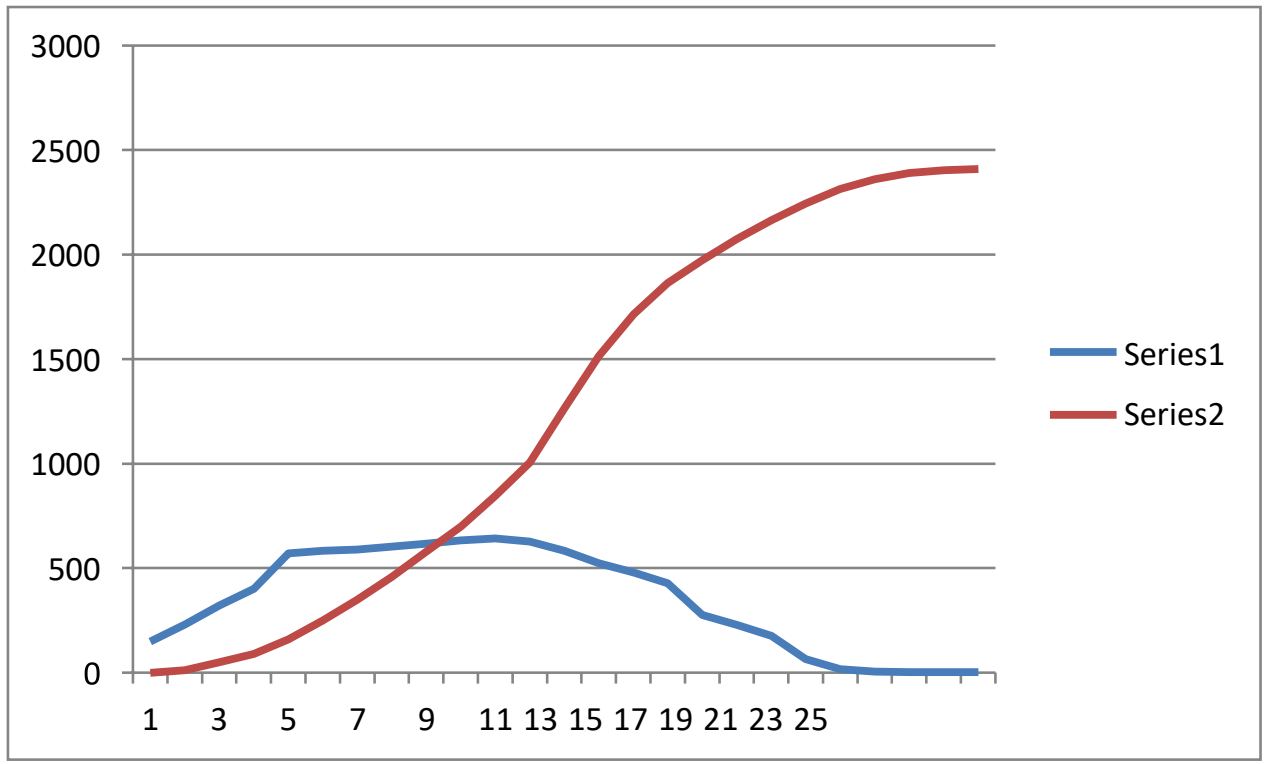

Fig 2: solarimter reading Vs cumulative water collected

Figure 2 shows the graph of cumulative fresh water collected with respected to solar radiation $\left(\mathrm{w} / \mathrm{m}^{2}\right)$ with respected to time. The readings are taken between morning 8 am to evening $8 \mathrm{pm}$.the cumulative fresh water collected with wind speed of $4 \mathrm{~m} / \mathrm{s}$ was $2410 \mathrm{ml}$, which is $15.1 \%$ higher than the water collected with wind speed of $3 \mathrm{~m} / \mathrm{s}$. where series 1 represented solari meter reading and series 2 represented cumulative water collected

\section{CONCLUSION}

Two double slope desalination stills are made tested with $4 \mathrm{~m} / \mathrm{s}$ and $3 \mathrm{~m} / \mathrm{s}$ wind velocity. Which means $17.8 \%$ increment in $4 \mathrm{~m} / \mathrm{s}$ it can be concluded that higher wind velocity gives more production per unit energy

\section{REFERENCES}

Amir M., Hassan F., and Mahmud A., 2018. Enhancing the performance of a solar driven hybrid solar still/humidification-dehumidification desalination system integrated with solar concentrator and photovoltaic panels, Desalination 430: 165-179

Deepak S.A, Sagar S., Kumar S., and Siddesha K.M, 2017. Solar desalination of seawater using a single-basin single sloped solar still with a parabolic concentrator, International Research Journal of Engineering and Technology (IRJET) 4: 1917-1921

Hasan M., and Arabi, M.A., 2013. Desalination and hot water production using solar still enhanced by external solar collector, Desalination and Water Treatment, 51: 1296-1300 
Sustainability, Agri, Food and Environmental Research, (ISSN: 0719-3726), 10(X), 2022:

http://dx.doi.org/

Hemin T., Sankhala, A., Ramana, P.V., and Panchal, H. 2018. A detailed review on solar desalination techniques, International Journal of Ambient Energy, 1490351(1-22)

Ma, Q., Ahmadi, A., Cabassud, C., 2018. Direct integration of a vacuum membrane distillation module within a solar collector for small-scale units adapted to seawater desalination in remote places: Design, modeling \& evaluation of a flat-plate equipment Journal of Membrane Science 564: 617-633

Morad M.M., Hend A.M. El-Maghawry, Kamal I.Wasfy, Improving the double slope solar still performance by using flat-plate solar collector and cooling glass cover, Desalination 373 (2015) 1-9

Mohammad A-H. Mousa A-A., Hasan M., and Zobaidah A., 2018. Solar desalination using solar still enhanced by external solar collector and PCM, Applied Thermal Engineering 128: $1030-1040$

Mousa A-A., Mohammad A-H. Hasan M., Zobaidah A., 2018. Theoretical investigation of solar desalination with solar still having phase change material and connected to a solar collector. Desalination 448: 60-68

Otero-Prado G., Martins-Vieira, L.G., Ribeiro-Damasceno, J.J. 2016. Solar dish concentrator for desalting water, Solar Energy 136: 659-667

Sharshir, S.W., Peng, G., Yang, N., El-Samadony, M.O.A., and Kabeel, A.E., 2016. A continuous desalination system using humidification - dehumidification and a solar still with an evacuated solar water heater, Applied Thermal Engineering doi: http://dx.doi.org/10.1016/j.applthermaleng.2016.05.120

Received: $15^{\text {th }}$ February 2021; Accepted: 04 $4^{\text {th }}$ May 2021; First distributed: 04 ${ }^{\text {th }}$ May 2021 